\title{
PENGEMBANGAN BUKU SAKU BERBASIS KEARIFAN LOKAL SEBAGAI SUMBER BELAJAR PADA MATERI BILANGAN
}

\author{
Harnisa Fitri ${ }^{1}$, Maharani Izzatin $^{2}$, Ferryansyah ${ }^{3}$ \\ ${ }^{1}$ Mahasiswa Strata 1 Pendidikan Matematika, Universitas Borneo Tarakan \\ 2,3 Jurusan Pendidikan Matematika, Universitas Borneo Tarakan \\ ${ }^{1}$ harnisafitri19@gmail.com \\ ²maharaniizzatinubt@gmail.com \\ 3vrsyah.math@gmail.com
}

\begin{abstract}
This research type was research and development which is conducted at SMP Negeri 8 Tarakan at VII class in Academic Year 2018/2019. The objective of this research was to develop the pocket book based on local wisdom as a learning source on number material that was suitable and practical for the seventh grade students of SMP Negeri 8 Tarakan.The development model used was ADDIE model modification. The ADDIE model consists of five stages that were consisted of: Analysis, Design, Development, and Evaluation. However, because of limitation time and limitation of the research objectives, so the researcher modified the ADDIE model modification by limiting the stage only in development stage. The product testing stage through two stages those were expert assessment and user response. In expert assessment was validated by the material experts, display experts and linguists. In the small group trials was carried out by 2 mathematics teachers and 6 students. On the field trial carried out by 26 students. The result of analysis shows that the product of pocket book based on local wisdom was developed based on validation by the material experts got a very suitable category with the percentage of $85.71 \%$, display experts got a very suitable category with the percentage of $86.25 \%$ and linguists got a very suitable category with the percentage of $85 \%$. Whereas based on the result in the field by the responses of student users got the percentage of $83.5 \%$ with a very practical category. Because the pocket book already fulfilled the suitable and practical requirements which consisting of aspects of the content or material feasibility, display feasibility, language feasibility, and practicality of user responses, so pocket book based on local wisdom can be used as a learning source on number material that suitable and practical for seventh grade students of SMP Negeri 8 Tarakan
\end{abstract}

Keywords: Development, Pocket Book Based on Local Wisdom, ADDIE Development Model.

\begin{abstract}
Abstrak
Jenis penelitian ini adalah penelitian dan pengembangan yang dilakukan di SMP Negeri 8 Tarakan pada kelas VII Tahun Ajaran 2018/2019. Penelitian ini bertujuan untuk mengembangkan buku saku berbasis kearifan lokal sebagai sumber belajar pada materi bilangan yang layak dan praktis untuk siswa kelas VII SMP Negeri 8 Tarakan.Model pengembangan yang digunakan adalah modifikasi model ADDIE. Model ADDIE terdiri dari lima tahapan yang terdiri dari: Analysis(analisis), Design (perancangan), Development (pengembangan), Implementation (implementasi) dan Evaluation (evaluasi). Namun, karena keterbatasan waktu dan pembatasan tujuan penelitian, maka pada penelitian ini peneliti memodifikasi model pengembangan ADDIE dengan membatasi hanya sampai tahap pengembangan (development). Tahap pengujian produk melalui 2 tahapan yaitu penilaian para ahli dan respon pengguna. Pada penilaian para ahli divalidasi oleh ahli materi, ahli tampilan dan ahli bahasa. Pada uji coba kelompok kecil dilakukan pada 2 guru matematika dan 6 siswa. Pada uji coba lapangan dilakukan pada 26 siswa. Hasil analisis menunjukkan bahwa produk buku saku berbasis kearifan lokal yang dikembangkan berdasarkan validasi oleh ahli materi memperoleh kategori sangat layak dengan persentase $85,71 \%$, ahli tampilan memperoleh kategori sangat layak dengan persentase $86,25 \%$ dan ahli bahasa memperoleh kategori sangat layak dengan persentase $85 \%$. Sedangkan dari hasil penelitian di lapangan oleh respon pengguna siswa diperoleh perentase $83,5 \%$ dengan kategori sangat praktis. Karena telah memenuhi syarat layak dan praktis yang terdiri dari aspek kelayakan isi atau materi, kelayakan tampilan, kelayakan bahasa, dan kepraktisan respon pengguna, maka buku saku berbasis kearifan lokal dapat digunakan sebagai sumber belajar pada materi bilangan yang layak dan praktis untuk siswa kelas VII SMP Negeri 8 Tarakan.
\end{abstract}

Kata kunci: Pengembangan, Buku Saku Berbasis Kearifan Lokal, Model Pengembangan ADDIE. 
Berdasarkan Undang-Undang Nomor 20 Tahun 2003, pendidikan adalah usaha sadar dan terencana untuk mewujudkan suasana belajar dan proses pembelajaran agar siswa secara aktif mengembangkan potensi dirinya (Arifin, 2014:40). Sejalan dengan hal diatas maka pendidikan nasional adalah pendidikan yang berdasarkan Pancasila dan UUD 1945 yang berdasar pada nilai-nilai agama, kebudayaan nasional Indonesia dan tanggap terhadap tuntutan perubahan zaman. Oleh karena itu, pelaksanaan pendidikan harus sesuai dengan kebudayaan bangsa Indonesia.

Kebudayaan nasional dibentuk dari kebudayaan daerah dan lokal yang didalamnya terdapat kearifan lokal. Pengenalan kearifan lokal dapat melalui pelajaran. Pelajaran matematika adalah salah satu mata pelajaran dalam sistem pendidikan di Indonesia. Pelajaran matematika tidak lepas dari segala aspek pendidikan maupun kehidupan, sehingga tidak lepas dari proses pembelajaran.

Komponen penting dalam proses pembelajaran yaitu sumber belajar. Buku merupakan salah satu bentuk sumber belajar. Buku yang baik adalah buku yang dikemas dengan menarik, efisien, inovatif, disesuaikan dengan kebutuhan siswa, serta dapat mengenalkan siswa akan kebudayaan yang terdapat di daerah siswa (kearifan lokal).

Buku paket pelajaran matematika yang ada dipasaran termasuk buku paket pelajaran yang digunakan siswa di SMP Negeri 8 Tarakan umumnya memiliki ukuran yang besar, tebal, berat, dan kalimat yang terlalu panjang karena memuat semua materi, serta belum banyak menunjukkan adanya upaya pengembangan KI.1 dan KI.2 dalam wujud perilaku berkarakter. Dengan kata lain, buku-buku paket tersebut belum banyak memuat makna pendidikan sebagai proses transformasi nilai-nilai budaya selain hakikat matematika sebagai mata pelajaran dalam proses pembelajaran.

Guru matematika SMP Negeri 8 Tarakan mengatakan bahwa sumber belajar yang digunakan dalam pembelajaran matematika masih terbatas pada buku paket dan LKS. Guru belum pernah membuat atau menggunakan sumber belajar lain selain buku paket yang tersedia di perpustakaan dan LKS yang dijual di koperasi sekolah. Selain itu, jumlah buku paket masih terbatas sehingga masih ada siswa yang kehabisan buku paket. Dalam proses pembelajaran masih terdapat siswa yang tidak membawa buku paket dan belum ada inisiatif siswa untuk membaca buku sebelum memulai pembelajaran atau pada saat jam kosong. Selain itu, sumber belajar yang selama ini siswa gunakan dalam pembelajaran matematika yang berupa buku paket dan LKS belum ada yang memuat pengenalan kearifan lokal.

Buku yang baik menurut guru matematika SMP Negeri 8 Tarakan adalah buku yang bisa membuat siswa senang membacanya serta memudahkan siswa untuk menggunakannya. Dalam proses pembelajaran, siswa kelas VII mengalami kesulitan dalam memahami materi bilangan. Menurut guru bidang studi, penyebab kesulitan siswa dalam memahami materi bilangan dikarenakan kurangnya pemahaman siswa pada materi tersebut serta siswa tidak mengulang kembali materi yang telah diajarkan di kelas, padahal kunci berhasilnya pembelajaran matematika adalah dengan mengulang kembali atau belajar dengan mengulang kembali materi. Hal ini berdampak kurang baik pada proses belajar dan mengajar karena siswa masih kurang aktif dan mandiri. 
Hasil wawancara terhadap siswa yang dilakukan pada tanggal 22 Februari 2018, siswa lebih tertarik dengan buku yang memiliki banyak gambar dan warna serta mudah untuk dibawa kemanamana. Namun pada kenyataannya, buku yang mereka gunakan dalam proses pembelajaran masih terbatas pada buku paket dan LKS. Buku paket yang mereka gunakan dalam proses pembelajaran berukuran besar serta tebal sehingga menyulitkan siswa untuk membawa buku saat akan belajar di kelas maupun di luar kelas. Sedangkan untuk LKS masih memiliki tampilan yang kurang menarik karena tidak berwarna dan memiliki sedikit gambar. Selain itu, berdasarkan wawancara siswa belum terlalu mengenal kearifan lokal yang mereka miliki.

Salah satu sumber belajar yang dapat digunakan oleh siswa sebagai solusi dari beberapa permasalahan diatas adalah penggunaan sumber belajar berupa buku saku berbasis kearifan lokal. Buku saku berupa buku kecil yang dapat digunakan sebagai sumber belajar. Selain itu, untuk menarik minat baca siswa penyajian buku saku didesain dengan menggunakan gambar dan warna yang lebih menarik serta terfokus pada satu materi yang dilengkapi dengan contoh soal serta latihan-latihan soal yang memuat pengenalan kearifan lokal. Buku saku yang dikembangkan melalui penelitian ini berukuran lebih kecil dibandingkan buku paket yang beredar selama ini. Sumber belajar ini dapat dibaca di mana saja serta dapat dibawa kemana-mana tanpa menambah beban barang bawaan dan yang paling penting yaitu dapat digunakan untuk belajar secara mandiri. Maka dari itu peneliti tertarik untuk meneliti dengan judul "Pengembangan Buku Saku Berbasis Kearifan Lokal Sebagai Sumber Belajar pada Materi Bilangan".

Sumber belajar pada dasarnya adalah segala sesuatu (dapat berupa benda, data, fakta, ide, orang, dan lain sebagainya) yang bisa menimbulkan proses belajar (Prastowo, 2015: 21). Sumber belajar dapat berupa buku-buku rujukan, objek, subjek, atau bahan dan alat untuk kegiatan pembelajaran (Akbar, 2013: 27). Adapun menurut Trianto (2010: 124) sumber belajar adalah segala sesuatu yang ada di sekitar lingkungan kegiatan belajar yang secara fungsional dapat digunakan untuk membantu optimalisasi hasil belajar. Selain itu, menurut Anitah (dalam Prastowo, 2015: 21) sumber belajar adalah segala sesuatu yang dapat digunakan untuk memfasilitasi kegiatan belajar.

Kata buku dalam bahasa indonesia memiliki persamaan dalam berbagai bahasa. Dalam bahasa Yunani disebut "biblos", dalam bahasa Inggris disebut "book", dalam bahasa Belanda disebut "boek", dan dalam bahasa Jerman adalah "das buch". Semua kata dasarnya diawali dengan huruf "b" sehingga besar kemungkinan semuanya berasal dari akar kata yang sama, yaitu dari bahasa Yunani. Jika dilihat dalam kamus masing-masing bahasa yang menggunakannya, kata itu pada hakikatnya memiliki makna yang sama dan dipergunakan untuk benda yang sama, yaitu kumpulan kertas yang dijilid (Sitepu, 2014:12). Selain itu, buku adalah kumpulan kertas berisi informasi, tercetak, disusun secara sistematis, dijilid serta bagian luarnya diberi pelindung terbuat dari kertas tebal, karton atau bahan lain (Sitepu, 2014:13). Ensiklopedia Indonesia (dalam Sitepu, 2014: 538) menjelaskan, dalam arti luas buku mencakup semua tulisan dan gambar yang ditulis dan dilukis atas segala macam lembaran papyrus, lontar, perkamen, dan kertas dengan segala bentuknya berupa gulungan, yang kemudian 
dilubangi, dan diikat atau dijilid muka dan belakangnya dengan kulit, kain, karton, dan kayu. Sementara itu, buku adalah lembar kertas yang berjilid, baik berisi tulisan maupun kosong (Prastowo, 2015: 167).

Salah satu bentuk buku yaitu buku saku. Buku saku merupakan sumber belajar yang berbentuk cetak. Menurut Setiawan (2010:173), buku saku adalah buku yang berukuran kecil yang dapat dimasukkan dalam saku dan mudah di bawa kemana-mana. Selain itu, Setyono (2013:118) berpendapat buku saku bisa diartikan sebagai buku yang berukuran kecil, ringan, mudah di bawa kemana-mana, dan bisa di baca kapan saja. Sedangkan menurut Hizair (2013:108) buku saku merupakan buku yang berukuran kecil yang dapat disimpan dalam saku dan mudah dibawa kemanamana.

Buku saku merupakan salah satu buku teks pelengkap. Menurut Prastowo (2015:168), buku teks pelengkap adalah buku yang sifatnya membantu atau merupakan tambahan bagi buku teks utama serta dapat digunakan oleh pendidik dan siswa. Menurut Peraturan Pemerintah Nomor 32 tahun 2013, suatu buku teks atau bahan ajar dinyatakan baik dan layak digunakan apabila memenuhi empat aspek kriteria kelayakan, yaitu kelayakan isi, bahasa, penyajian, dan kegrafikan. Penilaian buku teks pelajaran mengacu pada instrumen penilaian buku teks dari Badan Standar Nasional Pendidikan 2014 (Primesstianissa, 2012: 24).

Selanjutnya menurut Van den Akker (dalam Rochmad, 2012: 70) kepraktisan mengacu pada tingkat bahwa pengguna (atau pakar-pakar lainnya) memperimbangkan intervensi dapat digunakan dan disukai dalam kondisi normal. Selain itu, Nieveen (dalam Rochmad, 2012: 70) berpendapat bahwa untuk mengukur kepraktisan adalah dengan melihat mudah tidaknya guru dan siswa dalam memahami materi dan menggunakan buku saku. Tingkat kepraktisan ditentukan melalui angket respon guru dan siswa.

Menurut Wagiran (2012: 2) kearifan lokal dalam bahasa asing dikenal dengan kebijakan setempat (local wisdom), pengetahuan setempat (local knowledge) atau kecerdasan setempat (local genious). Kearifan lokal mempunyai ruang lingkup yang luas. Kearifan lokal lebih menekankan pada tempat dan lokalitas dari kearifan tersebut sehingga tidak harus merupakan kearifan yang telah diwariskan dari generasi ke generasi (Wagiran, 2012: 4). Menurut Wagiran dalam lingkup budaya, dimensi fisik dari kearifan lokal meliputi aspek: Upacara adat, cagar budaya, parawisata alam, transportasi tradisional, permainan tradisional, prasarana budaya, pakaian adat, warisan budaya, museum, lembaga budaya, kesenian, desa budaya, kesenian dan kerajinan, cerita rakyat, dolanan anak dan wayang.

Dari sisi filosofis dasarnya, this wisdom can be both abstract and concrete, but the important charachteristics are that it cames from experience or truth gained from life (Mungmachon, 2012: 176). Dari pendapat tersebut kearifan lokal dapat dibedakan menjadi dua aspek yaitu :

1. Bersifat abstrak. Maksudnya kearifan lokal yang tidak dapat diinderakan oleh manusia. Contohnya, gagasan, pemikiran, akal budi, pengetahuan, pandangan, serta nilai. 
2. Bersifat konkret. Maksudnya kearifan lokal yang dapat diinderakan oleh manusia.

Kemendikbud (dalam Najid, 2015:10) menyebut istilah kearifan lokal dengan keunggulan lokal, hal ini didasarkan dari istilah kearifan lokal yang terdiri dari dua kata yaitu kearifan (wisdom) dan lokal (local), sehingga kearifan lokal dapat juga disebut dengan local wisdom. Dalam disiplin ilmu antropologi local wisdom disebut juga dengan local genius, antropologi merupakan ilmu yang mempelajari manusia dalam bermasyarakat, bersuku bangsa, berperilaku, berkebudayaan, dan berperadaban. Begitu pula Ayatrohaedi (dalam Najid, 2015:11) menyatakan bahwa unsur budaya daerah potensial seagai local genius karena telah teruji kemampuannya untuk bertahan sampai sekarang.

Secara garis besar pengertian kearifan lokal adalah suatu keadaan atau potensi khas yang dimiliki oleh suatu daerah tertentu meliputi ekonomi, teknologi, budaya, informasi, komunikasi, ekologi serta cara bersikap dan bertindak masyarakat di daerah tersebut, dimana keadaan ini sudah seharusnya dijaga bahkan dikembangkan untuk menambah penghasilan suatu daerah (Najid, 2012:11).

Kota Tarakan adalah kota yang terletak di Pulau Tarakan, Kalimantan Utara. Kota Tarakan kaya akan kearifan lokal. Hal ini dibuktikan dengan keragaman masyarakat kota Tarakan. Suku asli dari pulau ini adalah suku Tidung. Menurut Datu Norbeck (dalam arbain, 2016: 4) selaku Budayawan kota Tarakan, kata Tidung lebih dekat dengan kata "Tidung-Tidong" merupakan sebuah kata yang lebih tepat dalam konteks penyebutan atau pelafalan mengenai arti gunung. Tidung atau Tidong secara harfiah adalah salah satu kelompok budaya tradisi yang terbentuk dari sabah dan sebagian Kalimantan Utara.

Terdapat beberapa kebudayaan masyarakat Tidung seperti seni rupa yang merupakan sesuatu hal yang diunggulkan oleh masyarakat Tidung Ulun Pagun. Seni pahatan sering ditemukan pada unsur alat musiknya, seperti ukiran naga yang saling berhadapan, alat musik agung, dan berbagai instrument bangunan baik rumah adat, perkantoran, dan lembaga pemerintahan yang mencirikan karakteristik penduduk asli. Selain itu terdapat seni batik. Kesenian batik ini kemudian kemudian dikembangkan oleh Dekranasda Kota Tarakan sebagai baju batik khas Tarakan. Hal ini juga merupakan bagian dari pelestarian kebudayaan local (Arbain, 2016: 100).

Salah satu contoh kearifan lokal Tidung terdapat dalam bentuk menjaga dan melestarikan ekosistem alam hutan bakau yang merupakan tempat hidup bagi salah satu jenis monyet yaitu bekantan. Bekantan merupakan jenis hewan darat yang hidup di area laut. Hal ini tergolong unik, sangat jarang sekali hewan yang hidup di daerah darat juga hidup di daerah kawasan laut. Inilah yang menyebabkan masyarakat Tidung Ulun Pagun menjaga dan melestarikan ekosistema alam yaitu hutan bakauSelain itu, terdapat nilai-nilai luhur seperti suka bekerja sama (tenguyun) (Arbain, 2016:103).

Suku tidung memiliki alat tangkap, permainan, dan makanan khasnya. Berikut adalah beberapa ragam alat tangkap dan alat permainan dalam mata pencaharian masyarakat Tidung dari hasil wawancara dengan Datu Norbeck (dalam Arbain, 2016: 266) antara lain: 
1. Alat tangkap Masyarakat Tidung: Tamba (Kelong), Bintul (Ambau), Ubu (Keramba), Jala, Pukat, Apon (Pancing), Sesiyut (Tangguk), Isit-isit

2. Alat Permainan Masyarakat Tidung antara lain: begegala (asinan), bejambi (petak umpet), beguli (kelereng), bitur, bebantung (lepokan), raga(takraw), lugu(logo), tegasing (gasing), ketikan(ketapel), marak (kelayangan), bebinti (main bente), pansa (panko), sapuk, leduman, yeyk, cabang, tilpun tali, gebokan, gelinding de ban, yuyuan (yoyo), gumbak ula, timbakan.

\section{METODE}

Jenis penelitian yang digunakan adalah jenis penelitian dan pengembangan atau Research and Development $(R \& D)$ dengan menggunakan model penelitian dan pengembangan ADDIE yang terdiri atas Analysis, Design, Development, Implementation and Evaluation. Pada pengembangan ini tahapan dari ADDIE dilakukan hanya sampai tahap ke 3 yaitu tahap Development (pengembangan).

Teknik pengumpulan data yang digunakan dalam penelitian ini adalah evaluasi dari beberapa ahli (ahli materi, ahli tampilan, dan ahli bahasa), subjek penelitian yakni 2 guru matematika dan 6 siswa sebagai subjek uji coba kelompok kecil dan 26 siswa sebagai subjek uji coba lapangan

Penelitian ini menggunakan dua macam analisis data, yaitu statistika deskriptif dan deskriptif. Analisis statistika deskriptif digunakan untuk menganalisis data yang diperoleh dari hasil validasi ahli dan angket respon guru dan siswa terhadap produk yang dikembangkan sedangkan analisis deskriptif merupakan analisis yang biasa digunakan untuk menganalisis data yang diperoleh melalui saran dari ahli materi, ahli tampilan, dan ahli bahasa serta dari uji coba produk yang dilakukan. Data jenis ini berupa suatu penjelasan berupa kata-kata yang menggambarkan keadaan. Hasil data disajikan dalam bentuk paparan kalimat dan data tertulis. Pada buku saku yang dihasilkan analisis deskriptif berupa kritik dan saran yang dikemukakan oleh para ahli, guru, dan siswa sebagai subjek penelitian.

Adapun pedoman penskoran tiap lembar validasi ahli dan respon guru menggunakan skala Likert oleh Sugiyono (2016: 166).

Tabel 1. Pedoman Penskoran dengan Skala Likert

\begin{tabular}{cc}
\hline Kriteria & Skor \\
\hline Sangat Baik (SB) & 4 \\
\hline Baik (B) & 3 \\
\hline Tidak Baik(TB) & 2 \\
\hline Sangat Tidak Baik (STB) & 1 \\
\hline Sumber : Sugiyono, 2016) &
\end{tabular}

Teknik analisis statistika deskriptif respon siswa berdasarkan skala likert.

Tabel 2. Pedoman Penskoran dengan Skala Likert

\begin{tabular}{cc}
\hline Kriteria & Skor \\
\hline Sangat Setuju (ST) & 4 \\
\hline Setuju (S) & 3 \\
\hline Tidak Setuju (TS) & 2 \\
\hline Sangat Tidak Setuju (STS) & 1 \\
\hline Sumber: Ambarwati, 2017) &
\end{tabular}

Data kelayakan melewati beberapa tahapan analisis dengan langkah-langkah sebagai berikut: 
1. Menghitung jumlah skor penelitian tiap indikator

2. Menghitung persentase kelayakan tiap aspek (\%)

Persentase Kelayakan $(\%)=\frac{\sum \text { jumlah skor tiap indikator }}{\sum \text { jumlah skor yang ideal }} \times 100 \%$

Data yang sudah terkumpul nantinya akan dianalisis dengan teknik analisis deskriptif kuantitatif yang diuraikan dalam persentase penilaian yang sudah ditentukan. Berikut tabel tentang kesesuaian aspek kelayakan menurut Arikunto (2010 : 158 ).

Tabel 3. Skala Persentase Uji Kelayakan

\begin{tabular}{cc}
\hline Presentase Penilaian & Kategori \\
\hline $81-100 \%$ & Sangat Layak \\
\hline $61-80 \%$ & Layak \\
\hline $41-60 \%$ & Cukup Layak \\
\hline $21-40 \%$ & Kurang Layak \\
\hline $0-20 \%$ & Tidak Layak \\
\hline
\end{tabular}

(Sumber : Arikunto,2010)

Kriteria kelayakan produk yang dikembangkan dapat dikatakan sudah layak digunakan apabila hasil penilaian dari ahli materi, ahli tampilan dan ahli bahasa memperoleh kategori minimal layak.

Data kepraktisan respon guru dan siswa melewati beberapa tahapan analisis dengan langkahlangkah sebagai berikut :

1. Menghitung jumlah skor penelitian tiap indikator.

2. Menghitung persentase kepraktisan tiap aspek (\%)

Persentase Kepraktisan $(\%)=\frac{\sum \text { jumlah skor tiap indikator }}{\sum \text { jumlah skor yang ideal }} \times 100 \%$

Data yang sudah terkumpul nantinya akan dianalisis dengan teknik analisis deskriptif kuantitatif yang diuraikan dalam persentase penilaian yang sudah ditentukan. Berikut tabel tentang kesesuaian aspek dalam kelayakan menurut Riduwan (2012:41).

\begin{tabular}{cc}
\multicolumn{2}{c}{ Tabel 4. Skala Persentase Uji Kepraktisan } \\
\hline $\begin{array}{c}\text { Presentase } \\
\text { Penilaian }\end{array}$ & Kategori \\
\hline $81-100 \%$ & Sangat Praktis \\
\hline $61-80 \%$ & Praktis \\
\hline $41-60 \%$ & Cukup Praktis \\
\hline $21-40 \%$ & Kurang Praktis \\
\hline $0-20 \%$ & Tidak Praktis \\
\hline
\end{tabular}

(Sumber: Riduwan, 2012)

Kriteria kepraktisan produk yang dikembangkan dapat dikatakan sudah praktis digunakan apabila tanggapan respon guru dan siswa memperoleh kategori minimal praktis.

\section{HASIL DAN PEMBAHASAN}

Pada tahap Analysis (Analisis) yaitu melakukan analisis kebutuhan, analisis kurikulum, dan analisis kearifan lokal kota Tarakan. Tahap Design (perancangan) merupakan tahap membuat rancangan awal buku saku. Tahap Development (pengembangan), buku saku mulai dibuat kemudian divalidasi oleh para ahli (ahli materi, ahli tampilan dan ahli bahasa). 
Hasil penelitian dan pengembangan buku saku berbasis kearifan lokal diuraikan dalam 2 aspek yaitu aspek kelayakan dan aspek kepraktisan. Masing-masing tahapan kegiatan penelitian dan pengembangan buku saku berbasis kearifan lokal yang dilakukan beserta analisis data yang diperoleh dapat dideskripsikan sebagai berikut:

\section{Aspek Kelayakan}

Pada aspek kelayakan dilakukan oleh para ahli meliputi validasi oleh ahli materi, ahli tampilan, dan ahli bahasa untuk mendapatkan saran dan perbaikan tentang kekurangan yang ada pada produk diantaranya yaitu:

\section{- Validasi Oleh Ahli Materi}

Hasil penilaian pada aspek isi atau materi memperoleh jumlah skor 24 dengan jumlah skor ideal tiap indikator 28 , sehingga diperoleh persentase sebesar $85,71 \%$ dan berada pada kategori sangat layak. Pada indikator kesesuaian materi dengan Standar Kompetensi (SK) dan Kompetensi Dasar (KD), kesesuaian materi dengan indikator, dan kesesuaian materi dengan tujuan pembelajaran, berada pada kategori sangat baik. Diperolehnya kategori sangat baik karena pada indikator yang dibuat sudah sesuai dengan apa yang dibutuhkan dalam buku saku. Selanjutnya, pada indikator kesesuaian contoh materi dengan kearifan lokal kota Tarakan, kejelasan penyampaian materi, sistematika penyampaian materi, dan kelengkapan materi berada pada kategori baik. Hal ini menunjukkan bahwa pada aspek isi atau materi yang disajikan dalam buku saku sangat layak untuk digunakan dalam pembelajaran matematika, namun harus dilakukan revisi dengan saran-saran yang diberikan. Saran yang diberikan adalah deskripsikan bagaimana sejarah bilangan, buat ulang perintah soal agar tidak bermakna kurang tepat, menambahkan unsur informasi baru, menambahkan informasi soal yang kurang dan soal perlu dibuat ulang yang sesuai

\section{- Validasi Oleh Ahli Tampilan}

Hasil penilaian pada aspek penyajian memperoleh jumlah skor 17 dengan jumlah skor ideal 20. Diperoleh persentase sebesar $85 \%$ berada pada kategori sangat layak. Aspek kegrafikan memperoleh skor 28 dengan jumlah skor ideal 32. Diperoleh persentase sebesar 87,5\%. berada pada kategori sangat layak. Total skor sebesar 45 dengan jumlah skor ideal 52. Diperoleh persentase sebesar $86,25 \%$ berada pada kategori sangat layak. Pada indikator kelengkapan penyajian, penyajian materi dilengkapi dengan gambar, ukuran buku saku, penggunaan warna, keterbacaan penulisan kalimat, kemenarikan sampul buku berada pada kategori sangat baik. Diperolehnya kategori sangat baik karena pada indikator yang dibuat sudah sesuai dengan apa yang dibutuhkan dalam buku saku. Selain itu, pada indikator penyajian materi sesuai dengan sistematika penulisan, keruntutan penyajian, kelogisan penyajian, penggunaan huruf, kemenarikan desain isi buku, ketepatan pemilihan jenis huruf, dan ketepatan pemilihan ukuran huruf berada pada kategori baik. Hal ini menunjukkan bahwa pada aspek penyajian dan kegrafikan yang 
disajikan dalam buku saku sangat layak untuk digunakan dalam pembelajaran matematika, namun harus dilakukan revisi dengan saran-saran yang diberikan. Saran yang diberikan adalah mengubah ukuran font menjadi 25 dan sebaiknya mengambil gambar sendiri, jika gambar tidak tersedia baru mengambil gambar di internet namun yang bebas hak cipta.

- Validasi Oleh Ahli Bahasa

Hasil penilaian pada aspek bahasa memperoleh total skor sebesar 17 dengan jumlah skor ideal 20. Diperoleh persentase sebesar $85 \%$ berada pada kategori sangat layak. Pada indikator kesesuaian dengan perkembangan siswa, kata atau ungkapan yang digunakan tidak menimbulkan penafsiran ganda atau salah pengertian berada pada kategori sangat baik. Diperolehnya kategori sangat baik karena pada indikator yang dibuat sudah sesuai dengan apa yang dibutuhkan dalam buku saku. Sedangkan pada indikator ketepatan penggunaan kata, kesesuaian penggunaan kalimat dengan kaidah penulisan Bahasa Indonesia yang baik dan benar, dan ketepatan penggunaan tanda baca, berada pada kategori baik. Hal ini menunjukkan bahwa pada aspek bahasa yang disajikan dalam buku saku sangat layak untuk digunakan dalam pembelajaran matematika, namun harus dilakukan revisi dengan saran-saran yang diberikan. Saran yang diberikan adalah perbaiki penggunaan huruf kapital, menambahkan kearifan lokal yang terdapat di kota Tarakan di mengenal kota Tarakan dan perbaikan struktur kalimat yang digunakan, menggunakan tanda baca yang benar.

\section{Aspek Kepraktisan}

Setelah dilakukan revisi produk dan hasilnya berkategori layak pada seluruh aspek sesuai dengan saran dari para ahli, kemudian dilanjutkan pada aspek kepraktisan. Data kepraktisan diperoleh dari angket respon yang diberikan kepada guru dan siswa.

\section{- Uji Coba Kelompok Kecil}

Uji coba kelompok kecil dilakukan pada 2 guru matematika dan siswa. Hasil tanggapan uji coba produk yang dilakukan oleh 2 guru memperoleh skor 34,5 dengan jumlah skor ideal 40. Diperoleh persentase sebesar $86,25 \%$ berada pada kategori sangat praktis. Pada indikator keunggulan dan kemenarikan diperoleh data kedua guru memberikan skor 4 berada pada kategori sangat baik. Hal ini dikarenakan menurut guru pada indikator kemudahan penggunaan produk, keefektifan waktu, dan keunggulan dan kemenarikan sudah sangat sesuai dengan buku yang harapkan. Selain data tersebut, diperoleh juga komentar umum guru yaitu "buku saku berbasis kearifan lokal ini sudah sangat bagus, praktis dan dapat diujicobakan kepada siswa”. Setelah diperoleh hasil uji coba produk yang dilakukan oleh 2 guru maka dapat dilanjutkan uji coba produk 6 siswa. Hasil tanggapan uji coba produk yang dilakukan oleh siswa memperoleh skor 33,2 dengan jumlah skor ideal masing-masing tiap indikator yaitu 40. Diperoleh perentase sebesar $83 \%$ berada pada kategori sangat praktis. Hal ini berarti siswa memberikan respon sangat positif pada penggunaan buku saku. Pada indikator kemudahan penggunaan produk, keefektifan waktu, 
keunggulan dan kemenarikan diperoleh hasil tanggapan uji coba produk yang dilakukan oleh siswa berada pada kategori sangat praktis. Hal ini berarti siswa memberikan respon sangat positif pada penggunaan buku saku, sehingga dapat dilanjutkan pada uji coba lapangan. Selain data tersebut, diperoleh juga komentar umum dan saran siswa pada uji coba kelompok kecil yaitu "buku saku ini sangat bagus karena memudahkan dalam belajar matematika, mudah dipahami dan terdapat kearifan lokal kota Tarakan yang disajkan dalam buku saku, sehingga siswa menjadi lebih mengetahui kearifan lokal kota Tarakan".

- Uji Coba Lapangan

Setelah diperoleh hasil uji coba kelompok kecil, maka dilanjutkan uji coba lapangan 26 siswa. Hasil tanggapan uji coba produk yang dilakukan oleh siswa memperoleh skor 33,4 dengan jumlah skor ideal masing-masing tiap indikator yaitu 40. Diperoleh perentase sebesar 83,5\% berada pada kategori sangat praktis. Pada indikator kemudahan penggunaan produk, keefektifan waktu, keunggulan dan kemenarikan diperoleh hasil tanggapan uji coba produk yang dilakukan oleh siswa dan berada pada kategori sangat praktis. Selain data tersebut, diperoleh juga komentar umum siswa pada uji coba lapangan yaitu "buku saku ini sangat baik dan menarik. Ukuran buku saku sesuai dengan kantong siswa sehingga mudah untuk dibawa kemana-mana. Materi yang disampaikan jelas, mudah dipahami dan dimengerti karena didalamnya membahas tentang kearifan lokal kota Tarakan sehingga bisa lebih banyak mengetahui kearifan lokal kota Tarakan”. Hal ini berarti siswa memberikan respon sangat positif pada penggunaan buku saku, sehingga siswa sebagai responden untuk mengukur kepraktisan menyatakan pada buku saku praktis untuk digunakan.

\section{KESIMPULAN}

Berdasarkan hasil penelitian pada tahapan validasi, buku saku berbasis kearifan lokal divalidasi oleh ahli materi pada aspek isi atau materi dan berada pada kategori sangat layak. Validasi oleh Ahli tampilan pada aspek penyajian dan kegrafikan berada pada kategori sangat layak, dan validasi oleh ahli bahasa pada aspek bahasa berada pada kategori sangat layak. Setelah mendapat kategori layak untuk digunakan, kemudian dilanjutkan pada tahap uji coba produk. Pada tahapan uji coba kelompok kecil ke 2 guru dan 6 siswa berada pada kategori sangat praktis. Tahap Uji coba kemudian dilanjutkan pada tahap uji coba lapangan pada 26 siswa dan berada pada kategori sangat praktis. Berdasarkan uraian di atas, maka dapat diambil kesimpulan bahwa pengembangan buku saku berbasis kearifan lokal layak dan praktis untuk digunakan sebagai sumber belajar untuk siswa kelas VII SMP Negeri 8 Tarakan. Sehingga tujuan pengembangan buku saku berbasis kearifan lokal yang layak dan praktis sebagai sumber belajar untuk siswa kelas VII pada materi bilangan telah tercapai. 


\section{DAFTAR PUSTAKA}

Akbar, Sa'dun. (2013). Instrumen Perangkat Pembelajaran. Bandung: PT Remaja Rosdakarya.

Ambarwati, Tira. (2017). Pengembangan Buku Saku Digital Menggunakan Model Pembelajaran Problem Solving Pada Materi Himpunan Siswa Kelas VII. Skripsi tidak dipublikasikan. IAIN Raden Intan Lampung.

Arbain,Muhammad. (2016). Buku Pintar Kebudayaan Tidung. Tarakan: Mutiara Ilmu.

Arifin, Zainal. (2014). Evaluasi Pembelajaran. Bandung: PT Remaja Rosdakarya.

Arikunto, Suharsimi. (2010). Dasar-dasar Evaluasi Pendidikan. Jakarta : Bumi Askara.

Mungmachon, Miss Roikhwamphut. (2012). Knowledge and Local Wisdom: Community Treasure. International Journal of Humanities and Social Science, Volume 2 Nomor 13 July 2012.

Najid, Annisah. (2015). Pengembangan Buku Suplemen Kimia Berbasis Kearifan Lokal Tangerang. Skripsi tidak dipublikasikan. UIN Syarif Hidayatullah Jakarta.

Prastowo, Andi. (2015). Panduan Kreatif Membuat Bahan Ajar Inovatif. Yogyakarta: DIVA Press.

Primesstianissa, Shinta. Pengembangan Buku Saku Ekonomi Sebagai Media Pembelajaran Untuk Meningkatkan Motivasi Belajar Ekonomi Siswa Kelas Xi Sma Negeri 2 Banguntapan. Skripsi tidak dipublikasikan. Universitas Negeri Yogyakarta.

Riduwan. (2012). Dasar-dasar Statistika. Bandung: Alfabeta.

Rochmad. (2012). Desain Model Pengembangan Perangkat Pembelajaran Matematika. Jurnal Matematika FMIPA UNNES. (Vol.3 No.1)

Setiawan, Ebta. (2010). Kamus Besar Bahasa Indonesia (KBBI) Offline Version 1.1.

Setyono.(2013). Pengembangan Media Pembelajaran Fisika Berupa Bulletin Dalam Bentuk Buku saku Untuk Pembelajaran Fisika Kelas VIII Materi Gaya Ditinjau Dari Minat Baca Siswa. Jurnal Bulletin Buku Universitas Sebelas Maret. Vol1.No.1, h.118.

Sitepu. (2014). Penulisan Buku Teks Pelajaran. Bandung: Remaja Rosdakarya.

Sugiyono. (2016). Metodologi Penelitian Kuantitatif, Kualitatif, dan R\&D. Bandung: CV Alfabeta.

Trianto. (2010). Mengembangkan Model Pembelajaran Tematik. Jakarta: Prestasi Pustakaraya.

Wagiran.(2012).Pengembangan Karakter Berbasis Kearifan Lokal Hamemayu Hayuning Bawana.Tersediadi:staffnew.uny.ac.id/.../Hamemayu+Hayuning+Bawana.pdf. Diakses pada tanggal 10 Maret 2018, Pukul 10.15 WITA. 